\title{
Isolation and Characteristics of Mesenchymal Stromal Cells from Different Parts of Placenta
}

Ekaterina Semenova', Zbigniew R Mrowiec ${ }^{2}$, Eugeniusz K Machaj', Magdalena Murzyn'1, Katarzyna Borg³, Dariusz Boruczkowski', Tomasz Ołdak $^{1}$

${ }^{1}$ Polish Stem Cell Bank, Famicord Group, Warsaw, Poland

${ }^{2}$ New Jersey Cord Blood Bank, Montvale, New Jersey, USA

IInstitute of Hematology and Transfusion Medicine, Warsaw, Poland

\begin{abstract}
Placenta performs the following functions: protection, nutrition, respiration, hormone production and excretion. As it is a great source of different cells, we are more and more interested to isolate them from the placenta. Cells can be harvested by non-invasive methods and without any ethical concerns. Due to its structure placenta contains Mesenchymal Stromal Cells (MSCs) of maternal and fetal origin. To make the selection easy, in our experiment we only used placentas from women who gave birth to boys. We used two methods to isolate MSCs (CD - collagenase digestion and MC - mechanical cut) from different parts of the placenta: amnion, chorion, villi and deciduae basalis.

MSCs were of $\mathrm{CD}^{+} 3^{+}, \mathrm{CD}^{+}{ }^{+}, \mathrm{CD} 105^{+}, \mathrm{CD} 14^{-}, \mathrm{CD} 19^{-}, \mathrm{CD} 34^{-}, \mathrm{CD} 45^{-}, \mathrm{HLA}-\mathrm{DR}-$ cell surface phenotype, adherent and capable to differentiate into osteocytes, adipocytes, chondrocytes. These data fulfilled minimal characterization criteria of MSCs.

We can isolate fetal and maternal MSCs from placenta. The origin of isolated cells was tested with the use of Fluorescence in situ Hybridization (FISH). MSCs isolated from the same placenta from one tissue can show different origins, for example, MSCs from chorion isolated by MC show maternal origin, but MSCs from the same amnion isolated using another method (CD) show fetal origin.

A placenta mostly consists of fetal-derived cells. However, close contact between fetal (amnion, chorion and villi) and maternal (decidua basalis) parts is responsible for presence of the maternal cells in the fetal part and fetal cells in the maternal part of a placenta. Isolation of pure: maternal or fetal MSCs from the placental tissue allows better characterization of MSC-based product for clinical purposes. If we are able to produce a pure population of maternal MSCs, we will gain the ability to apply a more personalized therapy for the mother.
\end{abstract}

Keywords: Mesenchymal stromal cells; MSC; Placenta; Cell therapy

\section{Introduction}

Today, there is a new field in the modern biomedicine the cell therapy, in which in vivo stem cells are transplanted to compensate for tissue dysfunction and regenerate damaged organs. Stem cells have two main features: self-renewal and the ability to differentiate into other cell types. They are a pool of undifferentiated progenitor cells of various types. The use of stem cells is the most promising direction of the cell therapy.

Stem cells are classified into embryonic and adult stem cells. Embryonic Stem Cells (ESCs) have a high potential for differentiation into many types of cells. The use of ESCs raises ethical questions and is associated with a high risk of cancer development. Additionally, ESCs express HLA, which leads to transplant rejection. In contrast, adult stem cells, for example mesenchymal stromal cells and hematopoietic stem cells can be isolated without any ethical problems using a noninvasive method.

Mesenchymal Stromal Cells (MSCs) are a good source for the cell therapy thanks to their properties. It was demonstrated that MSCs have the ability of self-renewal, secret factors that can facilitate tissue repair, and can differentiate into different types of cells, such as chondrocytes, adipocytes, osteocytes, cardiomyocytes, neuronal cells and other [1]. MSCs exert very important immunomodulatory effects: they suppress $\mathrm{T}$ - and B-cell proliferation and natural killer cells function, and they also limit the expression of the Major Histocompatibility Complex II (MHC II) [2,3]. Thanks to these properties, MSCs can be used in an effective therapy of the Graft-Versus-Host Disease (GVHD) [4,5]. It was shown that MSCs migrate to the sites of tissue injury (Table 1).
"Young" MSCs isolated from the placenta show a better proliferation and differentiation ability than "adult" MSCs [6]. For this reason, they have been used in a number of clinical trials (www.clinicaltrials.gov).

Friedenstein was the first to isolate and describe mesenchymal stromal cells from bone marrow [7]. It is known that the number of MSCs in the body, as well as their ability to proliferate and differentiate decline significantly with age [8].

The placenta is a very good source of a range of cells and hence has been attracting a growing interest. Cells can be harvested by non-invasive methods and without any ethical problems. Due to its structure, the placenta contains MSCs of maternal and fetal origin (Figure 1). The decidua basalis is a part of the endometrium adjacent to the myometrium. The decidua basalis is the best supplied with maternal blood and later expands to form the maternal part of the placenta. MSCs are also found in the amnion and the chorion - two fetal membranes,

*Corresponding author: Ekaterina Semenova, Działkowa, Polish Stem Cell Bank, Famicord Group, 85, 02-234 Warsaw, Poland, Tel: +22 436-40-50; Email: Ekaterina.Semenova@pbkm.pl

Received January 20, 2017; Accepted January 30, 2017; Published February 10,2017

Citation: Semenova E, Mrowiec ZR, Machaj EK, Murzyn M, Borg K, et al. (2017) Isolation and Characteristics of Mesenchymal Stromal Cells from Different Parts of Placenta. J Stem Cell Res Ther 7: 376. doi: 10.4172/2157-7633.1000376

Copyright: (c) 2017 Semenova E, et al. This is an open-access article distributed under the terms of the Creative Commons Attribution License, which permits unrestricted use, distribution, and reproduction in any medium, provided the original author and source are credited. 


\begin{tabular}{|l|l|l|}
\hline & Function & Literature \\
\hline INJURY & Tropism for sites of tissue injury & Spaeth et al., 2008 \\
\hline INFLAMMATION & $\downarrow$ T-limphocyte activation, macrophage infiltration & Park et al., 2011; Krampera et al., 2003 \\
\hline NEUROGENESIS & $\uparrow$ neuronal growth and differentiation & Prockop and Oh, 2012 \\
\hline SECRETION of factors & Secretion of angiogenic and neurotrophic factors & Baraniak and McDevitt, 2010; Drago et al., 2013 \\
\hline APOPTOSIS & $\downarrow$ apoptosis (apoptotic cell death) & Caplan and Dennis, 2006; Okazaki et al., 2008 \\
\hline NEURAL SYSTEM & $\begin{array}{l}\uparrow \text { proliferation and activation of astrocytes } \\
\uparrow \text { axonal remyelinization } \\
\uparrow \text { cerebral blood vessels } \\
\uparrow \text { synaptic connection } \\
\downarrow \text { microglia activation }\end{array}$ & van Velthoven, Kavelaars and Heijnen, 2012 \\
\hline
\end{tabular}

Table 1: Selected properties of MSCs which can be useful in the stem cell therapy.

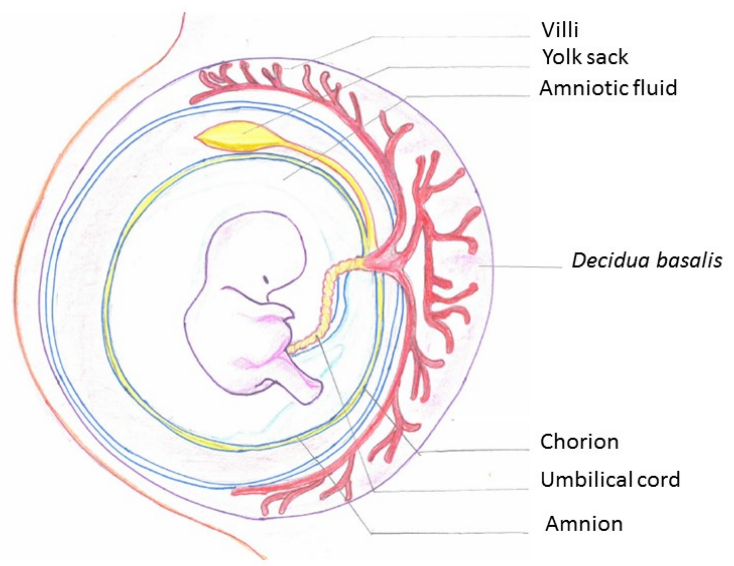

Figure 1: Structure of the placenta. We isolated MSCs from the amnion, the chorion, the villi and the decidua basalis.

and in the chorionic villi. We attempted to isolate MSCs of maternal and fetal origin from each of these parts of the placenta. If we are able to produce a pure population of maternal MSCs, we will gain the ability to apply a more personalized therapy for the mother.

\section{Methods}

\section{Term placenta sample collection}

Human full-term placentas were obtained from healthy women age 19-33 years, at the time of a routine caesarean section or vaginal delivery in an affiliated hospital in Cracow. The mean gestational age was 39 weeks (37-41 weeks). To facilitate the selection of donors, in our experiment we only used placentas of women who gave birth to boys. Placentas were collected in accordance with a protocol approved by the Committee of the Ministry of Health in Poland. Placentas were obtained from 18 donations: two from caesarean section and sixteen from vaginal delivery. We used two methods to isolate MSCs from different parts of the placenta: the amnion, the chorion, the villi and the decidua basalis $(\mathrm{Db})$.

\section{Cell isolation}

After dissection, tissue samples were washed with sterile PBS (phosphate buffered saline, $\mathrm{pH} 7.4$, ice-cold) and treated with antibiotics. Cells were isolated using two methods: Mechanical Cut (MC) and collagenase digestion (CD). Samples were cut into pieces, washed with PBS twice and incubated at $37^{\circ} \mathrm{C}$ in $75 \mathrm{~cm}$ flasks in Mesencult with a supplement and an antibiotic/antimicotic (MC), or with gentle rotation at $37^{\circ} \mathrm{C}$ with $1 \%$ collagenase IV (Gibco, Life Technologies) for 1.5 hours (CD). After collagenase digestion, cells were collected by centrifugation at $300 \mathrm{rpm}$ for $7 \mathrm{~min}$., followed by washing with DMEM with $10 \%$ FBS two times. Then the CD cells were resuspended in Mesencult (STEMCELL Technologies) with supplement and antibiotic/ antimicotic (Gibco) in $25 \mathrm{~cm}^{\wedge} 2$ flasks (BD Falcon), and cultured at $37^{\circ} \mathrm{C}$ in an atmosphere with $5 \% \mathrm{CO}_{2}$ and $90 \%$ of humidity. In the MC method, after one month of culturing the cells migrated from the tissues and adhere the flask surface. In the CD method, the cells were harvested after one to seven days of culturing (Figure 2). We used cells only from 1 or 2 passages.

\section{Flow cytometry}

For phenotypic evaluation, all the MSCs extracted from culture were incubated for $30 \mathrm{~min}$. with phycoerythrin-conjugated antibodies against the human antigens: CD73 (BD Biosciences), CD90 (BD Pharmingen, BD Biosciences), CD105 (BD Pharmingen, BD Biosciences), and fluorescein isothiocyanate-conjugated antibodies against the human antigens: HLA-DR, CD34, CD45, CD 19, CD14 (BD Bioscience). Samples were analyzed in a FACS Calibur machine (BD Bioscience). The minimal criteria for MSCs were: adherence to plastic; positive expression of CD73, CD90 and CD105; lack of expression of CD45, CD34, CD14, CD19 and HLA-DR; and the ability to differentiate into osteocytes, chondrocytes and adipocytes.

\section{Fluorescence in situ hybridization (FISH)}

Thirty seven fresh placental tissue samples (chorion, amnion, red tissue of placenta and separated villi fiber), after manual preparation and in vitro culture, were harvested according to standard cytogenetics procedures. After cell synchronization by colcemid for $20 \mathrm{~min}$ at $37^{\circ} \mathrm{C}$ $(10 \mu \mathrm{g} / \mathrm{ml}$, Biosera), pellet cells undergo a hypotonic treatment using $0.075 \mathrm{M} \mathrm{KCL}$ solution (Merck) for $20 \mathrm{~min}$ at $37^{\circ} \mathrm{C}$ to swell the cells. The cells were then fixed in cold Carnoy's fixative solution composed 3:1 methanol and $100 \%$ acetic acid (Merck) washed three times to ensure complete removal of cytoplasmic debris. The resulting suspension of metaphase and interphase cells was applied to microscopic slides. FISH was performed with the commercially available probe SE X(DXZ1)/Y (DYZ3) (Kreatech Diagnostics), dedicated for identification of aneuploidy. The procedure was applied according to the manufacturer's protocol. Slides were analyzed using an epifluorescence microscope Imager. Z2 (Carl Zeiss) and documented using an ISIS (Metasystems) Imaging System.

\section{Results}

We successfully were able to isolate MSCs from different parts of placenta. Morphologically, MSCs were fibroblast-like cells. We have not 


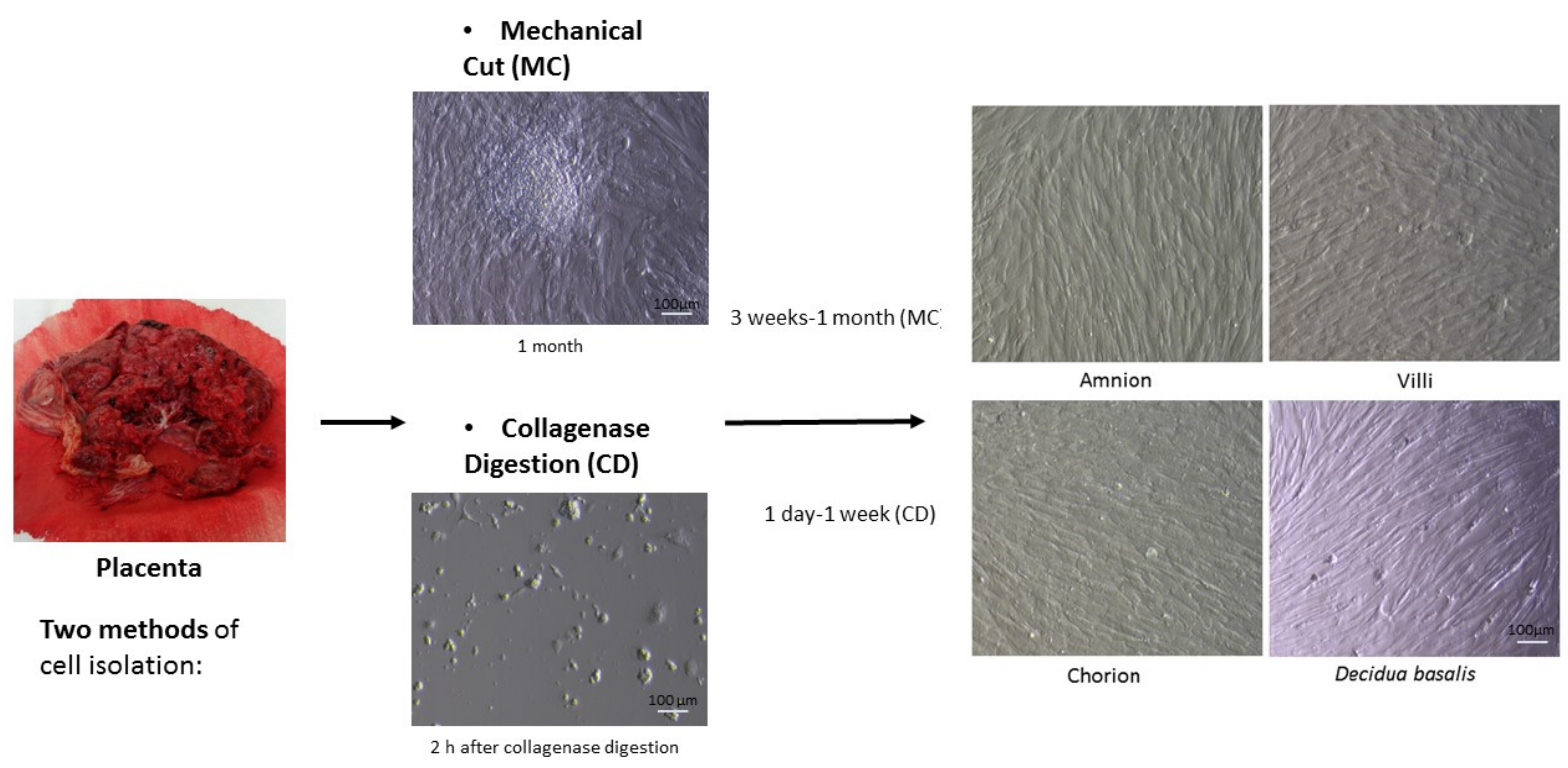

Figure 2: Cells were isolated from different parts of the placenta (the amnion, the chorion, the villi and the decidua basalis) with two different methods: mechanically and using collagenase.

noticed a significant morphological difference between cells isolated from different parts and by different methods. Process of differentiation of investigated cells into chondrocytes, adipocytes and osteocytes also looks very similar despite the part of placenta they came from.

\section{Flow cytometry}

Using cytometry, we searched for the following surface antigens of MSCs: $\mathrm{CD}^{+}{ }^{+}, \mathrm{CD}^{\circ}{ }^{+}, \mathrm{CD} 105^{+}, \mathrm{CD} 14^{-}, \mathrm{CD} 19^{-}, \mathrm{CD} 34, \mathrm{CD} 45^{-}$and HLA-DR. Every part of placenta shows the same immunophenotype (Figure 3).

\section{Differentiation}

The extracted MSCs were able to differentiate into osteocytes, adipocytes and chondrocytes (Figure 4). The differentiation of MSCs from different parts of placenta follows the same pattern. Therefore, they fulfilled the minimal characterization criteria of MSCs. Exemplary differentiations of the cells from decidua basalis are presented in Figure 4.

\section{Fluorescence in situ analysis (FISH)}

The origin of the isolated cells was tested using FISH method. Fluorescence in situ hybridization was performed mostly on interphase cells, and additionally on metaphase cells, to detect the number of copies of highly repetitive satellite DNA sequences located in the pericentric heterochromatin of chromosomes X and Y. between 107 to 728 cells were analysed per every sample. The FISH tests results are presented in Table 2.

In this experiment, we demonstrated that MSCs isolated from the same placenta and the same tissue can be of different origin, for example MSCs isolated mechanically (MC) from the chorion were of maternal origin, while MSCs from the same chorion sample isolated with the use of the Collagenase Method (CD) had fetal origin. MSCs isolated mechanically from the fetal part (chorion) of the placenta showed maternal contamination. MSCs from the amnion isolated by both methods showed maternal origin/contamination. It should be noted that the maternal part of the placenta (decidua basalis) had fetal contamination in the cells isolated mechanically (Figure 5). MSCs isolated by both $\mathrm{CD}$ and $\mathrm{MC}$ had different origin (Figure 6) and in the some cases - contamination by maternal or fetal cells.

The graphs show MSCs of maternal, fetal or mixed (maternal-fetal or fetal-maternal) origin by isolation group (CD or MC). MSCs from the chorion isolated by CD had more cells of maternal origin than MSCs isolated mechanically, while MSCs from the same tissue were generally of fetal origin. However, MSCs from chorionic villi and amnion isolated both by $\mathrm{CD}$ and MC had mostly fetal origin.

\section{Discussion and Conclusion}

The placenta consists of a larger fetal part (the membranes: chorion and amnion, villi) and a maternal part - decidua basalis. The placenta performs the following functions for the fetus: protection, nutrition, respiration, hormone production and excretion. The placenta grows throughout all pregnancy.

In the present study, we isolated fetal and maternal population of stem cells from different parts of the placenta. All the isolated MSCs had typical fibroblastic morphology, expressed cell-surface markers (CD73, CD90, CD105) and differentiated into a mesodermal lineage, a criterion recommended by the International Society of Cell Therapy.

Several protocols described two different methods of isolation: mechanical separation and enzyme digestion $[9,10]$. In our experiment, we isolated MSCs by mechanical cut and collagenase digestion to compare cell populations from a given tissue isolated with different methods. With the enzymatic method, MSCs can be obtained faster.

We successfully differentiated isolated cells into mesodermal lineage cells: osteocytes, chondrocytes and adipocytes.

A placenta mostly consists of fetal-derived cells. However, a close contact between fetal (amnion, chorion and villi) and maternal (decidua basalis) parts will lead to the presence of maternal cells in the fetal part 


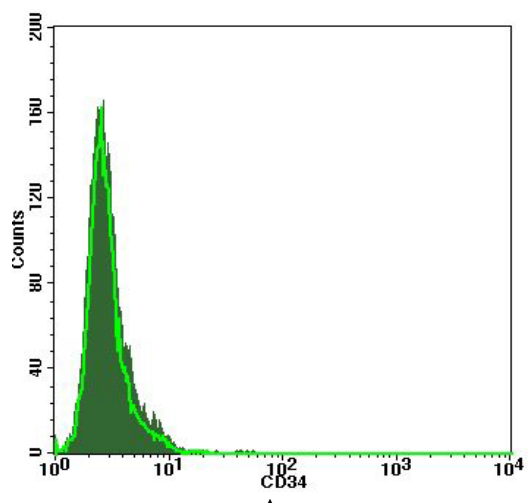

A

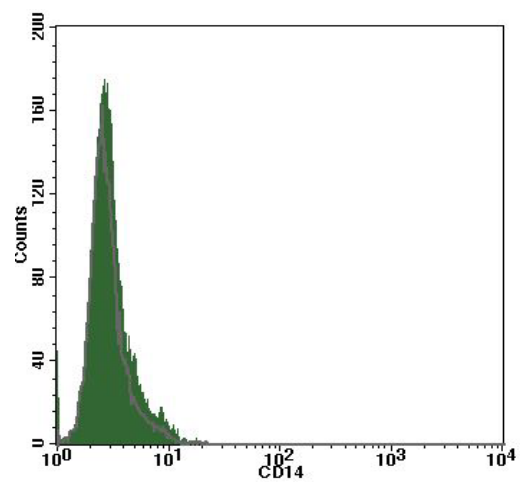

D

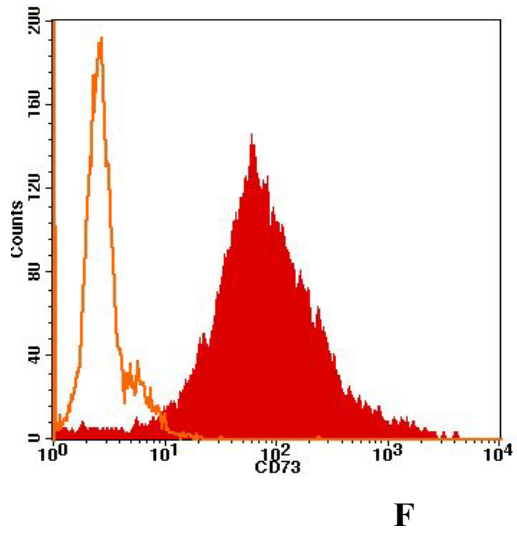

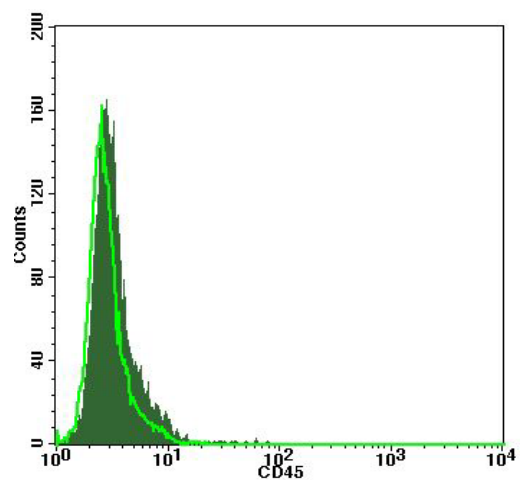

$\mathbf{B}$

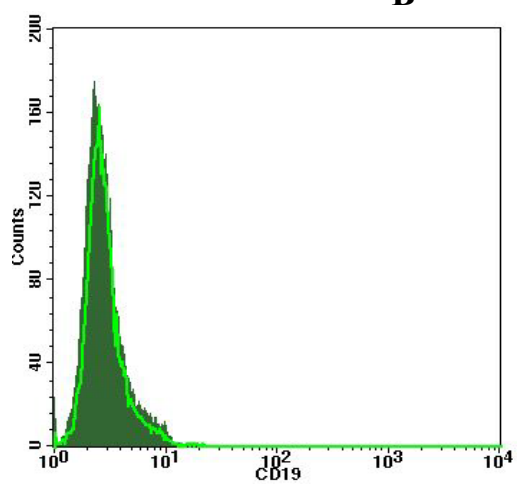

$\mathbf{E}$

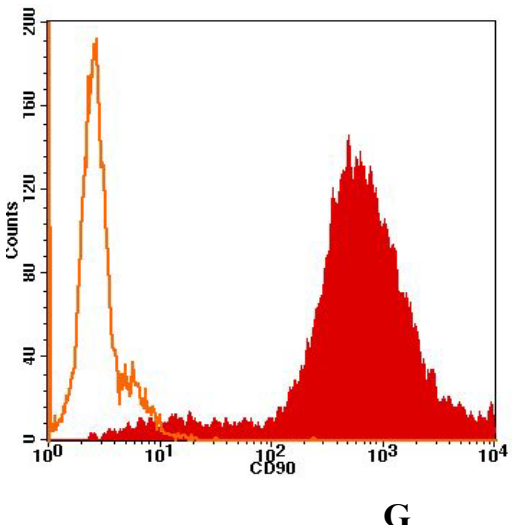

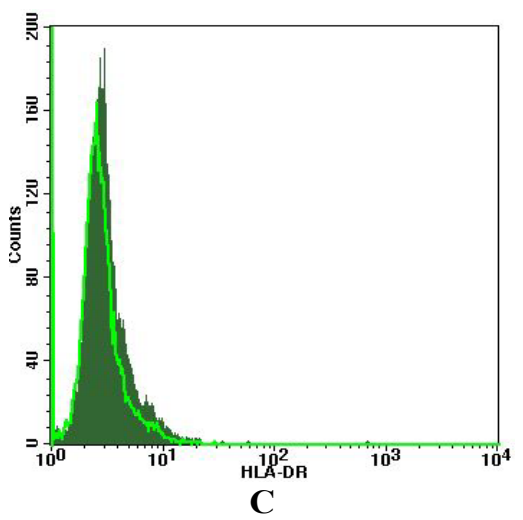

C

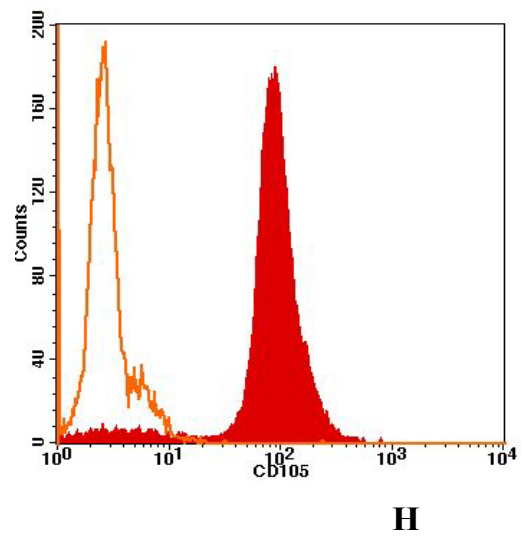

Figure 3: Exemplary flow cytometric histogram plots after immunopheno typing of placenta-derived MSCs from amnion. Transparent histograms represents cells population stain with polyclonal isotype control antibodies conjugated to fluorescein (FITC) or phycoerythrin (PE) (green or red, respectively). Filled histograms represent cell population labelled with monoclonal antibodies against CD34 (A), CD45 (B), HLA-DR (C), CD14 (D), CD19 (E), CD73 (F), CD90 (G), and CD105 (H) conjugated with fluorescein or phycoerythrin (green or red, respectively).

and fetal cells in the maternal part of the placenta. Our controversial FISH-results require further study and analysis.

During pregnancy maternal cells migrate into the fetus and fetal cells migrate into the mother $[11,12]$. Presence of maternal cells within the fetus: in the liver, skin, thymus [13]. Suggested that placenta is not a good barrier than previously thought. Maternal cells must to have ability to proliferate, because they have been found in adults [12]. In 2008 Chen and his team suggested that placental cells migration is connected with vascular endothelial growth factor A (VEGF A) [14]. Galazios et al. demonstrated that VEGF A concentration higher in the fetal circulation than in maternal that probably promote cell trafficking through placenta [15]. Nijagal et al. shown that inflammatory disease (autoimmune processes, complication during pregnancy, congenital anomalies and others) [16] during pregnancy changes cell trafficking [17]. Similar to maternal cells, fetal cells were detected into different maternal organs and tissues: liver, kidney, bone marrow [18]. In our study all mothers have cytomegalovirus (CMV), and some authors proofed that $\mathrm{CMV}$ can promote immune cell migration and increase the level of VEGF A $[19,20]$, which probably promote placental cell migration. 


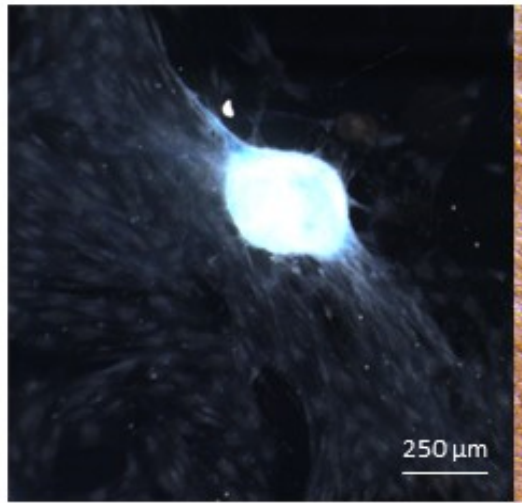

A

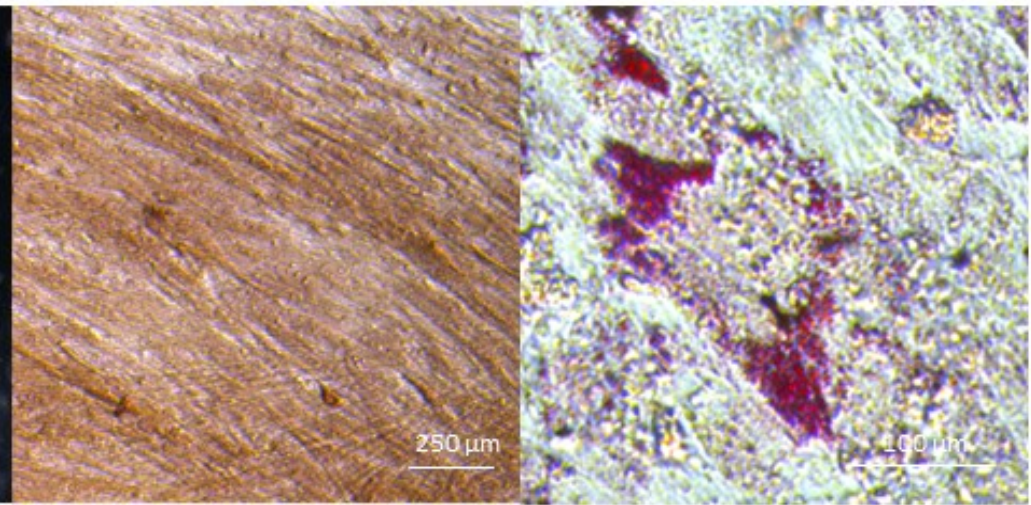

B
C

Figure 4: Exemplary multi-differentiation potential of MSCs isolated from the placenta (decidua basalis): A: alcian blue staining for cartilage proteoglycan, B: Alizarin Red staining for calcium deposits, C: Oil Red O staining for lipid droplets (red).

$C D$
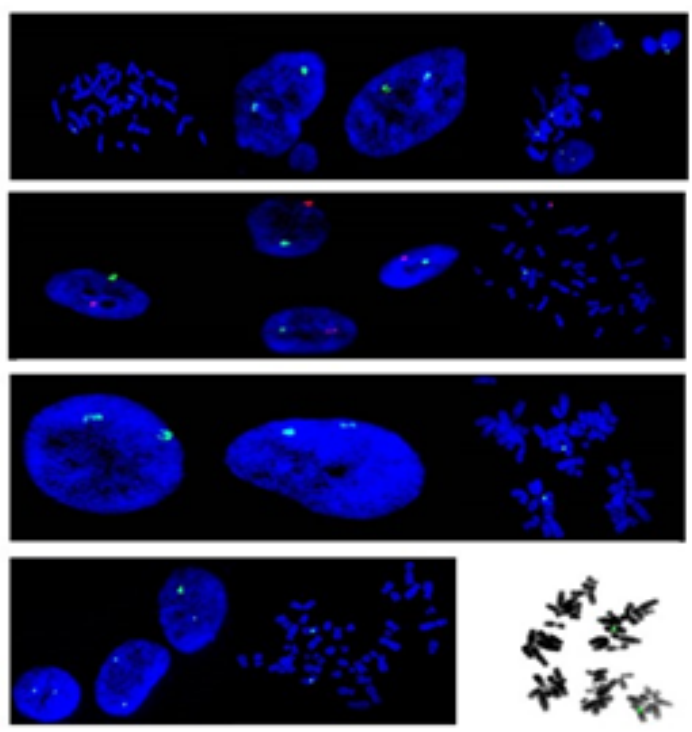

MC
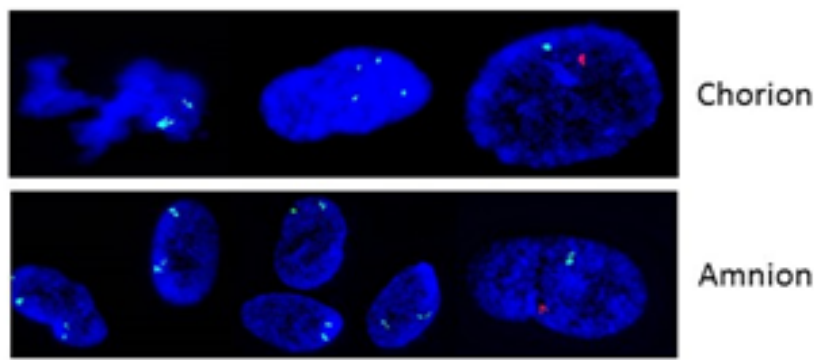

Amnion

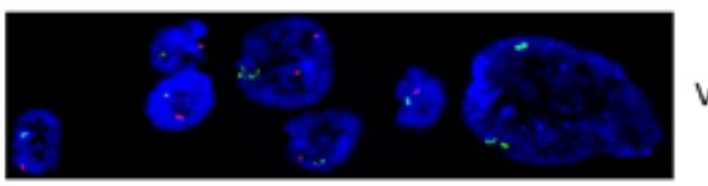

Villi

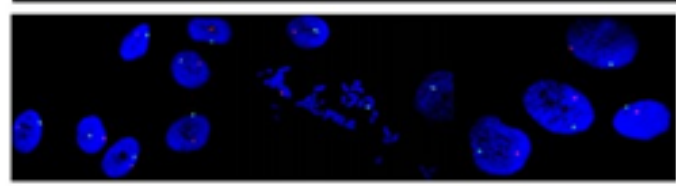

Deciduae basalis

SEX SEY

Figure 5: Selected FISH-results show that MSCs from the same parts of placenta, but isolated by collagenase method or mechanically can show different origin.

Some scientists suggested that fetal MSCs populations are contaminated by maternal cells that prevail after successive passages [21]. Others indicated that a population of fetal cells can be isolated without maternal contamination $[9,10,22]$. The possibility of isolation of a pure population of maternal or fetal MSCs depends on a wide variety of factors, such as the mother's diseases, etc.

Our research confirms that the placenta is an unique material, which contains MSCs of different origin: maternal and fetal. Both: collagenase digestion and mechanical cutting resulted in high amount of cells harvested, but usage of enzyme makes this process faster and less labor-consuming. Despite previous publication, decidua basalis is not the only part of the placenta which is rich in maternal cells. Villi, as well as amnion and chorion also contain maternal cells. Isolation of pure: maternal or fetal MSCs from the placental tissue allows better characterisation of MSC-based product for clinical purposes. Now there is no evidence that the pure population of maternal or fetal mesenchymal stem cells has better therapeutic capabilities. Probably, the banking and followed by clinical application of mixed population of maternal and fetal MSCs will potentially lead to a greater and interesting therapeutic effect. Further research is needed to verify this hypothesis [23-31].

\section{Acknowledgments}


Citation: Semenova E, Mrowiec ZR, Machaj EK, Murzyn M, Borg K, et al. (2017) Isolation and Characteristics of Mesenchymal Stromal Cells from Different Parts of Placenta. J Stem Cell Res Ther 7: 376. doi: 10.4172/2157-7633.1000376

Page 6 of 7

\begin{tabular}{|c|c|c|c|}
\hline Sample & Examined tissue & FISH results & summary of FISH results for given tissue \\
\hline \multicolumn{4}{|c|}{ Maternal tissue (XX) } \\
\hline 1 & decidua basalis & $x X-100 \%$ & \multirow{2}{*}{$\begin{array}{l}\text { One of the two samples showed contamination (both maternal and fetal } \\
\text { tissue were present). }\end{array}$} \\
\hline 2 & decidua basalis & $X X-57.9 \% ; X Y-42.1 \%$ & \\
\hline \multicolumn{4}{|c|}{ Fetal tissue (XY) } \\
\hline $1-6$ & villi & $X Y-100 \%$ & \multirow{8}{*}{$\begin{array}{l}46 \% \text { - fetal tissue (sex chromosomes } X Y \text { ). } \\
54 \% \text { - contamination (maternal and fetal tissue, } X X \text { and } X Y \text { ). }\end{array}$} \\
\hline 7 & villi & $X X-100 \%$ & \\
\hline 8 & villi & $X X-97 \% ; X Y-3 \%$ & \\
\hline 9 & villi & $X X-93.3 \% ; X Y-6.7 \%$ & \\
\hline 10 & villi & $X X-17.2 \% ; X Y-82.8 \%$ & \\
\hline 11 & villi & $X X-1 \% ; X Y-99 \%$ & \\
\hline 12 & villi & $X X-0.8 \% ; X Y-99.2 \%$ & \\
\hline 13 & villi & $X X-0.3 \% ; X Y-99.7 \%$ & \\
\hline $1-3$ & chorion & $x X-100 \%$ & \multirow{8}{*}{$\begin{array}{l}\text { None of the samples showed an image of sex chromosomes } \\
\text { corresponding to the male cell. } \\
30 \% \text { - maternal tissue }(X X) \text {. } \\
70 \% \text { - contamination (maternal and fetal tissue, } X X \text { and } X Y \text { ). }\end{array}$} \\
\hline 4 & chorion & $X X-98.6 \% ; X Y-1.4 \%$ & \\
\hline 5 & chorion & $X X-96.8 \% ; X Y-3.2 \%$ & \\
\hline 6 & chorion & $X X-81.2 \% ; X Y-18.8 \%$ & \\
\hline 7 & chorion & $X X-36.5 \% ; X Y-63.5 \%$ & \\
\hline 8 & chorion & $X X-2.9 \% ; X Y-97.1 \%$ & \\
\hline 9 & chorion & $X X-2.4 \% ; X Y-97.6 \%$ & \\
\hline 10 & chorion & $X X-0.3 \% ; X Y-99.7 \%$ & \\
\hline 1 & amnion & $x X-100 \%$ & \multirow{8}{*}{$\begin{array}{l}42 \% \text { - fetal tissue }(X Y) \\
58 \% \text { - contamination (maternal and fetal tissue, } X X \text { and } X Y \text { ). }\end{array}$} \\
\hline 2 & amnion & $X X-99.6 \% ; X Y-0.4 \%$ & \\
\hline 3 & amnion & $X X-84.8 \% ; X Y-15.2 \%$ & \\
\hline 4 & amnion & $X X-20.3 \% ; X Y-79.7 \%$ & \\
\hline 5 & amnion & $X X-19.5 \% ; X Y-80.5 \%$ & \\
\hline 6 & amnion & $X X-1.8 \% ; X Y-98.2 \%$ & \\
\hline 7 & amnion & $X X-0.2 \% ; X Y-99.8 \%$ & \\
\hline 8-12 & amnion & $X Y-100 \%$ & \\
\hline
\end{tabular}

Table 2: Some results of the FISH-analysis.
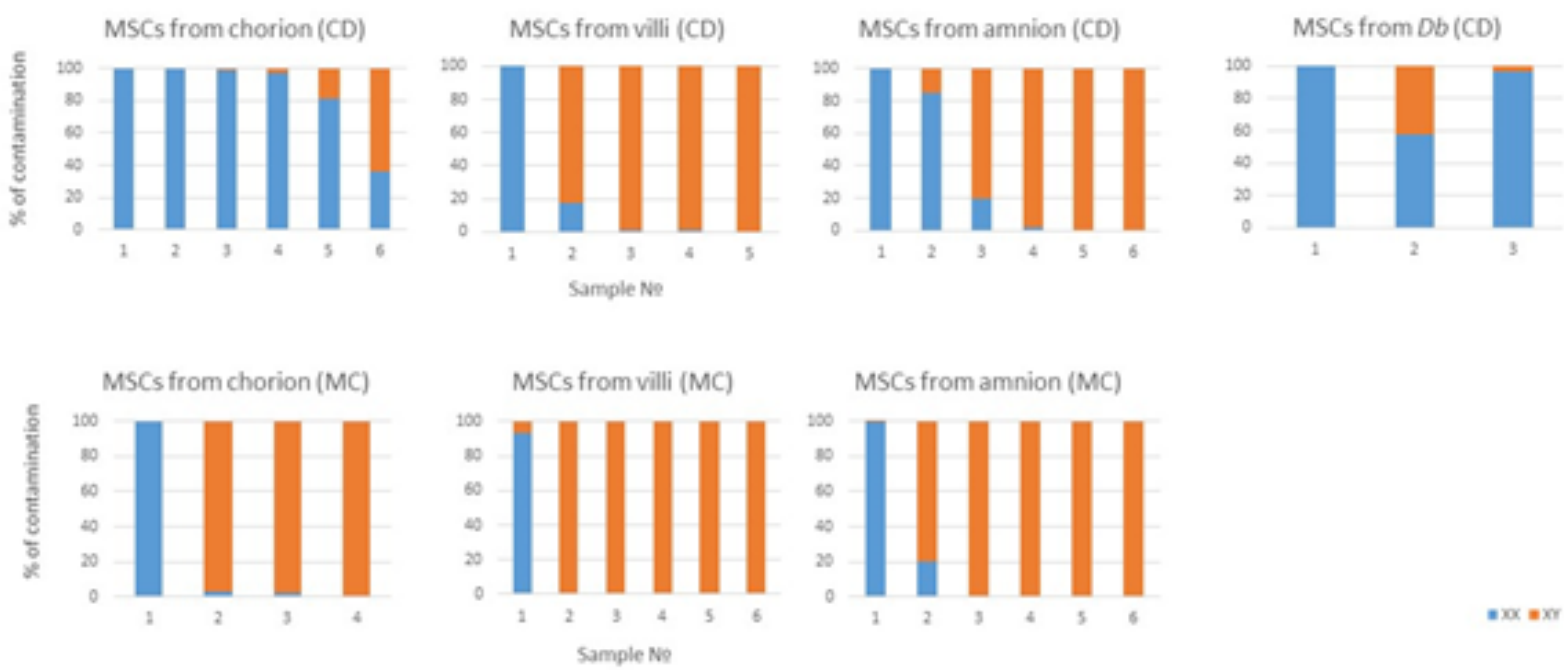

Figure 6: MSCs isolated by collagenase digestion (CD) and mechanical cut (MC) had different origin and contamination. Blue color shows cells of maternal origin, orange - cells of fetal origin.

The authors acknowledge the help of Kurilovich Ludmila for placenta's picture.

\section{References}

1. Ma S, Xie N, Li W, Yuan B, Shi Y, Wang Y (2014) Immunobiology of mesenchymal stem cells. Cell Death Differ 21: 216-225. [PubMed]
2. Griffin MD, Ritter T, Mahon BP (2010) Immunological aspects of allogeneic mesenchymal stem cell therapies. Hum Gene Ther 21: 1641-1655. [PubMed]

3. English K, Mahon BP (2011) Allogeneic mesenchymal stem cells: agents of immune modulation. J Cell Biochem 112: 1963-1968. [PubMed] 
Citation: Semenova E, Mrowiec ZR, Machaj EK, Murzyn M, Borg K, et al. (2017) Isolation and Characteristics of Mesenchymal Stromal Cells from Different Parts of Placenta. J Stem Cell Res Ther 7: 376. doi: 10.4172/2157-7633.1000376

4. Le Blanc K, Rasmusson I, Sundberg B, Götherström C, Hassan M, et al (2004) Treatment of severe acute graft-versus-host disease with third party haploidentical mesenchymal stem cells. Lancet 363: 1439-1441. [PubMed]

5. Wang S, Qu X, Zhao RC (2012) Clinical applications of mesenchymal stem cells. J Hematol Oncol 5: 19. [PubMed]

6. Roobrouck VD, Ulloa-Montoya F, Verfaillie CM (2008) Self-renewal and differentiation capacity of young and aged stem cells. Exp Cell Res 314: 19371944. [PubMed]

7. Friedenstein AJ, Gorskaja JF, Kulagina NN (1976) Fibroblast precursors in normal and irradiated mouse hematopoietic organs. Exp Hematol 4: 267. [PubMed]

8. Stolzing A, Jones E, McGonagle D, Scutt A (2008) Age-related changes in human bone marrow-derived mesenchymal stem cells: Consequences for cell therapies. Mechanisms of Ageing and Development, 129: 163-173. [PubMed]

9. Zhang Y, Li C, Jiang X, Zhang S, Wu Y, et al. (2004) Human placenta-derived mesenchymal progenitor cells support culture expansion of long-term cultureinitiating cells from cord blood CD34 + cells. Exp. Hematol 32: 657-664. [PubMed]

10. Fukuchi Y, Nakajima H, Sugiyama D, Hirose I, Kitamura T, et al. (2004) Human placenta-derived cells have mesenchymal stem/progenitor cell potential. Stem Cells 22: 649-658. [PubMed]

11. Gammill HS, Guthrie KA, Aydelotte TM, Adams Waldorf KM, Nelson JL (2010) Effect of parity on fetal and maternal microchimerism: interaction of grafts within a host? Blood 116: 2706-2712. [PubMed]

12. Maloney S, Smith A, Furst DE, Myerson D, Rupert K, et al. (1999) Microchimerism of maternal origin persists into adult life. J Clin Invest 104: 41-47. [PubMed]

13. Srivatsa B, Srivatsa S, Johnson KL, Bianchi DW (2003) Maternal cell microchimerism in newborn tissues. J Pediatr 142: 31-35. [PubMed]

14. Chen CP, Lee MY, Huang JP, Aplin JD, Wu YH, et al. (2008) Trafficking of multipotent mesenchymal stromal cells from maternal circulation through the placenta involves vascular endothelial growth factor receptor-1 and integrins. Stem Cells 26: 550-561. [PubMed]

15. Galazios G, Papazoglou D, Giagloglou K, Vassaras G, Koutlaki N, et al. (2004) Umbilical cord serum vascular endothelial growth factor (VEGF) levels in normal pregnancies and in pregnancies complicated by preterm delivery or pre-eclampsia. Int J Gynaecol Obstet 85: 6-11. [PubMed]

16. Derderian SC, Jeanty C, MacKenzie TC (2016) Feto-maternal cell trafficking and labor. Fetal Stem Cells in Regenerative Medicine. Springer Science + Business Media New York United States of America.

17. Nijagal A, Wegorzewska M, Jarvis E, Le T, Tang Q, et al. (2011) Maternal T cells limit engraftment after in utero hematopoietic cell transplantation in mice. J Clin Invest 121: 582-592. [PubMed]

18. Koopmans M, Kremer Hovinga ICL, Baelde HJ, Fernandes RJ, de Heer E, et al (2005) Chimerism in kidney, livers and hearts of normal women: implication fo transplantation studies. Am J Transplant 5: 1495-502. [PubMed]

19. Vomaske J, Nelson JA, Streblow DN (2009) Human Cytomegalovirus US28: A Functionally Selective Chemokine Binding Receptor. Infect Disord Drug Targets 9: 548-556. [PubMed]

20. Reinhardt B, Schaarschmidt P, Bossert A, Luske A, Finkenzeller G, et al. (2005) Upregulation of functionally active vascular endothelial growth factor by human cytomegalovirus. J Gen Virology 86: 23-30. [PubMed]

21. Wulf GG, Viereck V, Hemmerlein B (2004) Mesengenic progenitor cells derived from human placenta. Tissue Engineering 10: 1136-1147.

22. Soncini M, Vertua E, Gibelli L, Zorzi F, Denegri M, et al. (2007) Isolation and characterization of mesenchymal cells from human fetal membranes. J Tissue Eng Regen Med 1: 296-305. [PubMed]

23. Spaeth E, Klopp A, Dembinski J, Andreeff M, Marini F (2008) Inflammation and tumor microenvironments: defining the migratory itinerary of mesenchymal stem cells. Gene Ther 15: 730-738. [PubMed]

24. Park MJ, Shin JS, Kim YH, Hong SH, Yang SH, et al. (2011) Murine mesenchymal stem cells suppress $\mathrm{T}$ lymphocyte activation through IL-2 receptor $\alpha(C D 25)$ cleavage by producing matrix metalloproteinases. Stem Cell Rev. 7: 381-393. [PubMed]

25. Krampera M, Glennie S, Dyson J (2003) Bone marrow mesenchymal stem cells inhibit the response of naive and memory antigen-specific $T$ cells to their cognate peptide. Blood 101: 3722-3729. [PubMed]

26. Prockop DJ, Oh JY (2012) Mesenchymal Stem/Stromal Cells (MSCs): Role as Guardians of Inflammation. Mol Ther 20: 14-20. [PubMed]

27. Baraniak PR, McDevitt TC (2010) Stem cell paracrine actions and tissue regeneration. Regen Med 5: 121-143. [PubMed]

28. Drago D, Cossetti C, Iraci N, Gaude E, Musco G, et al. (2013) The stem cell secretome and its role in brain repair. Biochimie 95: 2271-2285. [PubMed]

29. Caplan Al, Dennis JE (2006) Mesenchymal stem cells as trophic mediators. J Cell Biochem 98: 1076-1084. [PubMed]

30. Okazaki T, Magaki T, Takeda M (2008) Intravenous administration of bone marrow stromal cells increases survivin and $\mathrm{Bcl}-2$ protein expression and improves sensorimotor function following ischemia in rats. Neurosci Lett 430 109-114. [PubMed]

31. van Velthoven CTJ, Kavelaars A, Heijnen CJ (2012) Mesenchymal stem cells as a treatment for neonatal ischemic brain damage. Pediatr Res 71: 474-481. [PubMed] 